\title{
Margaret Mead, Derek Freeman a Samoa
}

\author{
Martin Soukup \\ Katedra sociologie, andragogiky a kulturní antropologie, Filozofická fakulta Univerzity Palackého v Olomouci \\ Do redakce doručeno 4. března 2015; k publikaci přijato 17. dubna 2015
}

\section{MARGARET MEAD, DEREK FREEMAN AND SAMOA}

\begin{abstract}
The objective of the article is an analysis of Freeman-Mead controversy. Czech academia rarely deals with this controversy; if any Czech scholars present the dispute, they do so only in general terms. Dozens of scholars are involved in the controversy. It demonstrates the importance of the case for a development of anthropological theory and methodology. The aim of the study is to provide an overview of the history of the controversy and to present arguments of all involved sides. The controversy is also put into the context of the development of American anthropology.
\end{abstract}

KEY WORDS Polynesia; Samoa; cultural determinism; Mead; Freeman; controversy

ABSTRAKT Předmětem studie je analýza a interpretace kontroverze Freeman versus Mead. V českém prostředí je uvedený spor prezentován výjimečně a vždy v obecné poloze. Do sporu o výzkum Margaret Mead se dosud zapojily desítky akademiků, což svědčí o významu sporu pro antropologii. Cílem studie je přetlumočit podstatu sporu, shrnout a prezentovat hlavní argumenty a uvést spor do kontextu vývoje amerického antropologického myšlení.

KLÍČOVÁ SLOVA Polynésie; Samoa; kulturní determinace; Mead; Freeman; kontroverze

\section{ÚVOD}

Kritické přehodnocení výzkumu provedeného americkou kulturní antropoložkou Margaret Mead (1901-1978) na souostroví Samoa se stalo předmětem zájmu antropologů již mnohokrát. Do středu pozornosti se slavné samojské výzkumy dostaly hlavně díky novozélandskému antropologovi Dereku Freemanovi (1916-2001), jenž ve dvou knihách a řadě zveřejněných studií opakovaně kritizoval Mead a její odbornou kompetenci. Konkrétně zpochybnil její znalost samojštiny, obvinil ji z názorové předpojatosti, odmítl její postupy při terénním výzkumu (viz hlavně Freeman 1983, 1999). Od začátku osmdesátých let, kdy vešly ve známost Freemanovy nesmlouvavé názory na Mead, tiskem vyšlo množství knih a studií, jejichž autoři se snaží posoudit relevantnost Freemanových argumentů a důkazů a spor vyjasnit (např. Holmes 1988, Shankman 1996, 2009). Kritické texty, recenze a dopisy do časopisů vydaly na objemný svazek již před čtvrt stoletím (Caton 1990). Je proto zajímavé, že česká antropologická literatura až na výjimky (Vrhel 2010) ${ }^{1}$ prezentuje spor velmi zjednodušeně a spor vyznívá spíše ve prospěch Freemana. ${ }^{2}$ Ivo T. Budil alespoň poukázal na výhrady vůči Freema-

1 František Vrhel (2010) v doslovu k české edici klasické práce od Mead (2010) jako jeden z mála přibližuje spor a upozorňuje na rozsáhlost sporu Freeman versus Mead. Vrhelův doslov je také vynikajícím shrnutím života a díla Margaret Mead.

2 Česká antropologie se životu a dílu Margaret Mead dosud věnovala jen okrajově. Jediná knižní práce přeložená do češtiny vyšla teprve nedávno (Mead 2010). Nejstarší zmínku o Mead jsem našel ve Voráčkovi (1941). S ohledem na politickou situaci v socialistickém Československu a dobové postavení antropologie se odkazy na její dílo až na výjimky neobjevovaly. Důležitou práci odvedl Josef Wolf (1927-2012), jenž se zasloužil o otištění úryvků z jejích děl (viz Wolf 1971a, 1971b). Český čtenáŕ se s jejími názory mohl „obeznámit“" kupř́kladu v překladové propagandistické práci Anglo-americká ethnografie ve službách imperialismu (Kramařík \& Nahodil 1953). 


\begin{tabular}{|c|c|c|}
\hline antropolog / antropoložka & Období & monografie \\
\hline Margaret Mead & $1925-1926$ & $1928 c, 1930[1969]$ \\
\hline Felix Keesing & $1930-1933$ & 1934 \\
\hline Lowell Holmes & $1953-1954$ & 1958 (disertační práce) \\
\hline Melvin Ember & $1955-1956$ & 1981,1988 \\
\hline Richard Moyle & $1966-1969$ & - \\
\hline Richard Alan Goodman & $1968-1969$ & 1979 \\
\hline Penelope Schoeffel & $1973,1976-1977$ & 1977 (disertační práce), 1982 \\
\hline Bradd Shore & 1968 (součást mírových sborů), 1971 & 1998 \\
\hline Jeanette Marie Mageo & $1981-1989,1990,1991$ & 2006 \\
\hline John Derek Freeman & $1940-1943,1965-1968,1981$ & \\
\hline
\end{tabular}

Tabulka 1 vybraní antropologové a antropoložky, kteří uskutečnili terénní výzkum na Samoi (Pouze jsem vybral část antropologů, kteří se věnovali studiu kultury na Samoi. Jmenovat lze řadu dalších akademiků, jako jsou kupříkladu Bonnie Nardi, Sharon Tiffany či Robert Maxwell.)

novi, jež vznesl Paul Shankman v polovině devadesátých let (viz Budil 2003: 247-248), Václav Soukup zůstává v obecné rovině a prakticky nepřipouští, že by se mohl Freeman mýlit, označuje jej podle mého soudu nepřiměřeně za odborníka na samojskou kulturu světového významu (Soukup 2004: 395396). ${ }^{3}$ Freeman rozhodně nečněl nad specialisty, za jaké lze považovat např́klad Melvina Embera (1933-2009), Bradda Shorea (narozen 1945) a další specialisty na kulturu souostroví Samoa (viz tabulka č. 1). Navíc se v zahraniční literatuře setkáváme s přesvědčením, že Freemanem artikulovaná kritika je tendenční a navíc je zjevné, že ji nezřídka vedl v osobní rovině. Občas se rovněž uvádí, že Freeman vykazoval známky narušené osobnosti (Lutkehaus 2008). České antropologické texty prezentují výsledky výzkumu Mead na Samoa výhradně na základě Coming of Age in Samoa (Dospívání na Samoi, 1928), popularizačního díla zpracovaném pro vydavatelství William Morrow se sídlem v New Yorku. Přitom to nebyla jediná práce, kterou tato antropoložka věnovala Samoa (viz např. Mead 1928a, 1928c, 1928e, 1929, 1930 [1969], 1937). Ostatně platí to stejnou měrou o dalších výzkumech, jež Mead uskutečnila. Často o výsledcích výzkumu vydala nějaké popularizační dílo, ale současně také odbornou vědeckou monografii jednoznačně svědčící o zvládnutí „řemesla“"

Na samotný spor mohli čeští antropologové reagovat se zpožděním, nebở zde odborné texty z oblasti kulturní antropologie vycházely jen výjimečně. Našel jsem pouze jediný text $\mathrm{z}$ osmdesátých let, jenž reflektoval spor (Rensberger 1984), jedná se o překlad článku vydaného v Science v roce 1983.

3 Soukup se při prezentaci výzkumu na Samoi a sporu o něj opírá o výše citovaný přehledový článek od Rensbergera (1984), z nějž přejal de facto citace z díla Margaret Mead i další tvrzení.

4 Výsledky výzkumu na ostrově Manus popsala v populární knize Growing up in New Guinea (Vyrůstání na Nové Guineji, 1930), po níž následovala odborná monografie věnovaná př́ibuzenství na Admiralitních ostrovech (viz Mead 1930, 1934). To stejné platí o výzkumu v Sepiku, z nějž vzešla popularizační kniha Sex and Temperament in Three Primitive Societies a později pentalogie věnovaná Arapešům (viz Mead 1935, 1938, 1940, 1947a, 1947b, 1949; viz též Soukup 2013).
Předchozím konstatováním není dotčena otázka, nakolik lze Mead vůbec pokládat za přední reprezentantku americké kulturní antropologie. To je problém vhodný pro samostatnou studii, proto se omezím jen na stručné shrnutí vlastního postoje. Ztotožňuji se sice s některými Freemanovými kritickými výhradami (viz poslední část studie), ale nelze Mead upřít významný př́nos k rozvoji antropologického myšlení. Stála u zrodu antropologického studia genderu a sexuality (Mead 1935, 1964), přispěla ke sblížení hledisek psychologie (a psychiatrie) a antropologie (Mead 1952), její vliv na rozvoj vizuální antropologie je nepřehlédnutelný (Bateson - Mead 1942, Mead - MacGregor 1953). Freemanův důkladný rozbor a kritika díla Mead o Samoi může vzbudit mylný dojem, že celé její dílo je od základu chybné. Proto je namístě upozornit, že předmětem Freemanovy kritiky je pouze to, co Mead publikovala o Samoa. Freeman sám zdůraznil, že si velmi cení úspěchů, jichž jinak dosáhli Mead a další reprezentanti „boasiánského paradigmatu“ (1983: xiii).

\section{PRELUDIUM SPORU}

Mead i Freemana $\mathrm{v}$ řadě oblastí mnohé spojuje, oba nejdřive studovali psychologii, první terénní zkušenosti nabyli na Samoi, rádi polemizovali a dokázali svými názory provokovat. Oba sice zkoumali samojskou kulturu, nicméně v různých obdobích a na jiných ostrovech. Oba lze označit za přinejmenším výstřední osobnosti, ve Freemanově případě se dá dokonce hovořit o narušené osobnosti. $\mathrm{K}$ jejich osobnímu setkání došlo pouze jednou. V Canberře se oba antropologové doslova střetli v roce 1964. Freeman později vzpomínal, jak jej Mead požádala o jeho diplomovou práci, aby se s ní mohla obeznámit, než budou druhý den diskutovat. S koktáním jí přislíbil zapůjčení textu k prostudování („klepete se jako sulc“, mu prý tehdy Mead řekla). Přiznal, že z ní měl trochu strach. Mead nakonec zapůjčenou diplomovou práci zapomněla u něj v kanceláŕi. Když se druhý den do sebe na semináři za př́tomnosti studentů pustili, Mead se jej dotázala, proč jí tedy svou 
diplomovou práci, kterou se neustále ohání, nedonesl na pokoj? K překvapení všech odpověděl: „Protože jsem se bál, že byste po mě chtěla, abych zůstal přes noc“. Freeman o desetiletí později v rozhovoru pro tisk uvedl, že Mead „kastruje“ muže, vyhledává je, aby je srazila na kolena. Z řady textů je evidentní, že Freeman byl Mead doslova posedlý, sám uvedl, že jí byl zcela zhypnotizován (Barrowclough 1996: 36-37). Opakovaně zasílal Mead dopisy, ale $\mathrm{k}$ jejich veřejnému stř̌etnutí došlo právě jen v roce 1964. Mnozí antropologové vytýkají Freemanovi, že se do boje s Mead pustil až pět let po její smrti. Sám Freeman nicméně uvedl, že v roce 1977 Mead dopisem nabídl prostudovat si téměř hotový rukopis. Freeman uvedl (1983: xvi), že na výzvu nedostal žádnou odpověd', nicméně v rozhovorech uváděl, že mu asistentka odpověděla, že Mead je př́liš nemocná (Shankman 2009: 66, 21). Nejasností kolem kontroverze je dosud př́liš mnoho, proto nadále vzbuzuje pozornost $\mathrm{v}$ antropologické obci.

\section{MEAD A SAMOA}

Margaret Mead projevila zájem o Polynésii již v čase doktorského studia pod vedením Franze Boase na Kolumbijské univerzitě. Zpracovat teoreticky založenou disertační práci zvládla za dva roky, což se v té době pokládalo za přiměřené, dnes by Meadovou spíše podezrrívali jako „rychlostudentku“ a „rychlokvašku“, nebot řádné zpracování tématu si vyžádá obvykle mnoho let (Shankman 2009: 85). Disertační práci Mead věnovala problematice stability vybraných kulturních komplexů v Polynésii. Její práce byla reakcí na probíhající teoretické diskuze o difuzionismu se zvláštním zřetelem ke Greabnerovi a Riversovi (viz Mead 1928b: 9, 1969: xiv). ${ }^{5}$ Konkrétně se v práci zabývala analýzou tří kulturních komplexů: výroba kánoí, stavba domů a tetování. Jedná se o teoreticky založenou a komparativně zaměřenou kvalifikační práci, v níž každý kulturní komplex studovala na prŕíkladu vybraných polynéských kultur: Havaj, Markézy, Nový Zéland (Maori), Tahiti a Samoa (Mead 1928a). Pasáže věnované Samoi pro potřeby tištěného vydání revidovala s využitím poznatků nabytých při terénním výzkum.

Je celkem pochopitelné, že Mead toužila nejen těžit $\mathrm{z}$ poznatků získaných rešerší a studiem odborných pramenů, ale nabýt etnografická data z první ruky. Nutnost vypravit se na terénní výzkum si v plné síle uvědomila při účasti na 92 . výroční konferenci Britské asociace pro pokrok vědy, jež se konala od 7. do 13. srpna $1924 \mathrm{v}$ Torontu, kde také sama vystoupila. Mezi jejími posluchači figurovali přední antropologové té doby - Alfred Cort Haddon (1855-1940), Aleš Hrdlička

5 Je zajímavé, že rozhodnutí pro Polynésii bylo motivováno nezbytnou jazykovou př́pravou. Boas totiž Mead navrhl tři lokality, u nichž se lze zabývat kulturní stabilitou - Sibiř, Holandsko a Polynésie. První dvě Mead vyloučila, jelikož by to znamenalo osvojit si ruštinu a čínštinu v prvém př́padě a středověkou latinu a starou vlámštinu v př́ípadě druhém. Polynésie vyžadovala jen francouzštinu a němčinu (Mead 1969: xiv).
(1869-1943), Alexander Goldenweiser (1880-1940), Edward Sapir (1884-1939), Charles Seligman (1873-1940) či Clark Wissler (1870-1947). Mead měla podle programu přednášku s názvem Rank in Polynesia (Hodnost v Polynésii), v níž se měla zabývat systémy hodností na Samoji, Havaji a Novém Zélandě (viz Sapir 1924). Sama však uvedla, že proslovila př́íspěvek na téma tetování (Mead 1969: xiv). Setkání s kolegy, z nichž mnozí nabyli bohaté terénní zkušenosti, ji motivovalo k uskutečnění vlastního empirického výzkumu. Volba místa a tématu bylo výsledkem kompromisu dosaženého při vyjednávání Mead s Boasem. Ten zamýšlel vyslat ji k nějaké skupině nativních Američanů, aby studovala období dospívání (Mead 172: 125-128). Mead se naopak chtěla vypravit do Polynésie s cílem zkoumat kulturní změnu. Cestu do Polynésie Boas podmínil pravidelným dopravním spojením na vybraný ostrov, proto odmítl její původní úmysl pracovat na izolovaném ostrově Tuamotu. Konečnou volbou se stala Americká Samoa. Mead vzpomíná, že když se nakonec vypravila do Tichomoří, poprvé v životě se ocitla sama, do té doby nikdy necestovala do zahraničí, nemusela hovořit cizím jazykem, nestála na palubě lodi (Mead 1977: 19).

Mead dostala pro realizaci výzkumu grant, jenž jí kryl podstatnou část nákladů na cestu do Polynésie, kde zůstala v rozsahu necelých devíti měsíců. Při výzkumu si předsevzala studovat adolescentní děvčata $s$ cílem zjistit, zda také v „primitivni“ společnosti představuje dospívání období „bouře a stresu“, jak předpokládali američtí psychologové (Hall 1904). Nejdříve pobývala $\mathrm{v}$ Pago Pago, kde v rozsahu dvou měsíců pracovala na své samojštině a hledala vhodnou lokalitu, kde by mohla provádět terénní výzkum. $Z$ dopisů adresovaných Boasovi plyne, že vybírala pečlivě. Pátrala po izolované lokalitě, kde žije dostatek dospívajících děvčat. Současně vyžadovala, aby místo zůstávalo ve spojení s většími sídelními centry. Proto padla její volba na Ta’u, malý ostrov ve skupině Manu’a, jenž se nachází ve vzdálenosti $110 \mathrm{~km}$ od Tutuila, hlavního ostrova Americké Samoy (Mead 1977: 28-29). Tam strávila čas výzkumem od 9. listopadu 1925 do 16. dubna, tedy v souhrnu 158 dní (Freeman 1999: 264-265). Zde podle svých slov spolupracovala se 68 dívkami, $50 \mathrm{z}$ nich podrobila detailnímu studiu (Mead 1928: 282).

Z terénního výzkumu na Samoi vzešly především tři rozsáhlejší práce. Nejznámější se stalo dílo Dospivání na Samoi, jež bylo revidovanou a "light verzi“ zprávy nazvané The Adolescent Girl in Samoa (Dospívající dívka na Samoi, 1927), kterou autorka odevzdala Národní radě pro výzkum jako výsledek terénního výzkumu. Ta následně Mead umožnila na její žádost vydat text jako komerční knihu. Vydavatel William Morrow, jenž se díla ujal, autorku přiměl, aby dílo rozšíríila a upravila tak, aby mohlo zaujmout širší čtenářskou obec (Mead 1972: 165). Většina sociálních komentářů se v původní zprávě neobjevuje, autorka je vložila až do Dospívání na Samoi (Shankman 2009: 102). Dílo lze jen stěží považovat za odbornou monografii, ačkoli se knize tento status přikládá na základě četné citovanosti v odborné literatuře. Ostatně již ve stejném roce Franz Boas v díle Anthropology and Modern Life (Antropologie a moderní život, 1928) Dospívání na Sa- 
moi cituje, aby dokumentoval možnosti zbavit období dospívání obtíží a stresů (Boas 1962: 190). Jenže sama Mead nepřeceňovala význam Dospívání na Samoi. Mead v díle předložila kritiku amerického stylu výchovy. V předmluvě k poslednímu vydání, jež za jejího života vyšlo, vyjádřila přání, aby se kniha četla s vědomím, že pojednává o Samoi v období 1926-1928. Výzvy na revidování díla striktně odmítla s odůvodněním, že kniha musí zůstat ve stavu, jenž odpovídá stavu poznání a metod v době, kdy dílo vzniklo. Současně komentovala nařčení z falzifikace dat, jehož se jí dostalo od nejmenovaných ${ }^{6}$ výzkumníků, kteří nedokázali dekódovat skutečnou totožnost informátorek a přezkoumat tak její závěry, nebot Mead jejich identitu utajila. $Z$ etických důvodů odmítla na této věci cokoli měnit (Mead 1973: xiv-xvi).

Protože se domnívám, že se v českých učebnicích a přehledech dějin oboru opakují zjednodušené pravdy o Dospívání na Samoi, dovolím si stručně rekapitulovat otázku, na kterou se pokouší dát Mead dílem odpověd. Poselství Dospívání na Samoi lze porozumět jen v kontextu doby, kdy dílo vznikalo, a publika, pro nějž jej Mead psala. Knihu nepsala pro odborné auditorium, jednalo se o sociální kritiku Ameriky, kterou předložila angažovaná antropoložka. Působivým jazykem, jenž dokládá její nezpochybnitelný literární talent, se zde zabývá otázkou kulturní determinace. Testuje přesvědčení zastávané americkou veřejností i odborníky, že období dospívání se vyznačuje rebelií vưči autoritám, zmatky a vzrůstajícím idealismem, jež jsou podmíněny biologickým dospíváním organismu. $\mathrm{V}$ knize se nepokouší dát odpověd’ na otázku po biologické a kulturní determinaci vůbec, ale táže se, zda „bouře a vzdor“ doprovází tuto fázi života, protože jsou lidé adolescenty, nebo protože jsou adolescenty ve Spojených státech (Mead 1928: 5). Klíčem k porozumění dílu Dospívání na Samoi je jeho podtitul: A Psychological Study of Primitive Youth for Western Civilization (Psychologická studie primitivní mládeže pro potřebu západní civilizace). Jiným slovy, jedná se o knihu, jejímž cílem bylo přispět k diskuzi o nejvhodnějších způsobech výchovy americké mládeže. Samojská kultura zde měla pro americkou společnost posloužit jako pomyslné zrcadlo.

Mead neprezentuje samojskou kulturou jako zcela bezkonfliktní a dospívání místních dívek jako úplně poklidné, jak to dokládá již název 11. kapitoly - Dívka v konfliktu. Popisuje generační konflikty a rovněž tělesné trestání dětí. Nicméně je evidentní, že Mead podcenila význam konfliktů a napětí v samojské společnosti a místo toho označila dospívání na Samoi za období „spořádaného rozvoje soustavy dozrávajících zájmu a činností" (Mead 1928: 157). Ve srovnání s americkými protějšky autorka prezentuje samojské dívky jako pokrokové. Podle svědectví Mead si dívky dopřávaly předmanželského sexu a jejich dospívání probíhalo převážně poklidně a bez stresu. Mead vysvětluje nižší míru konfliktu na Samoi celkově menší možností dívek vybírat si mezi alternativami, kam směřovat

6 Zjevně se jednalo o Freemana, jenž ji ve věci odhalení identity informátorek kontaktoval dopisem. Dříve uvedla, že ji v obdobné věci oslovil rovněž Lowell Holmes (Mead 1969: xix). další život. „Samoa nezná než jeden zpưsob života, jemuž učí své děti“, píše Mead (1928: 248). Před jejich americkými protějšky stály zásadní volby, jež předurčovaly budoucnost každého z nich - odložit sňatek a děti? Co si zvolit za profesi? Jít studovat? Jaký zvolit studijní obor? Rozsáhlé množství možností lze pokládat za stresor, jenž v dospívajících lidech vyvolával stres, nejistoty a zmatky, jak se správně rozhodnout. Navíc zde existovaly generační rozdíly $\mathrm{v}$ názorech na život a sexualitu. Ve dvacátých letech procházela americká společnost významnými změnami, mladí lidé začínali vést nezávislý život, měnili se postoje $\mathrm{k}$ předmanželskému sexu a partnerským vztahům. Právě tyto kulturní změny většinová společnost $\mathrm{z}$ řad učitelů, vychovatelů, psychologů či politiků vnímala jako „bouři a vzdor" vůči zavedeným pořádkům a normám. Pro mladé lidi nebyla situace jednoduchá. Vzdorováním představám rodičů o správném životním stylu, ztráceli jejich přízeň a podporu. Pokud se drželi názorů rodičů a chovali se podle jejich představ, neprrijímali je jejich vrstevníci. To vše je podle Mead důsledkem př́liš heterogenní americké společnosti, v níž se každá rodina snaží prosadit vlastní představu kázně a soubor norem (Mead 1928: 241). Mead knihu psala sama za sebe a vyjadřovala $\mathrm{v}$ ní vlastní názory na výchovu, nedržela se při prezentaci Samoy Malinowského imperativu zachytit „hledisko domorodce“ (Malinowski 1922: 25). Samojská kultura měla $\mathrm{v}$ jejím záměru srovnávací funkci při rozboru výchovných stylů v americké společnosti (srov. Shankman 2009: 108-110). Mead v knize de facto hájí liberální výchovu, jež může zmírnit či prrímo odstranit „bouři a vzdor" v období dospívání u americké mládeže. Klíčem k řešení stavu je podle Mead umožnit mladým lidem svobodně si zvolit svůj život a jejich volby neodsuzovat a nepodrobovat ostré kritice. Témata výchovy a formování osobnosti tvořily jádro odborného zájmu Mead, opakovaně se k nim z různých hledisek vracela i v dalších výzkumech, jež uskutečnila v celkem osmi různých kulturách Pacifiku, Indonésie a nativního obyvatelstva Severní Ameriky (viz tabulka 2).

Jedinou odbornou monografií sepsanou Mead o Samoi je Social Organization of Manua (Sociální uspořádání Manua, 1930) ${ }^{7}$, již vydalo prestižní Bernice Bishop Museum. Do druhého vydání Mead připojila text, jenž je pozoruhodný z hlediska sporu, jenž po jejím úmrtí vyvolal svými knihami a studiemi Freeman. Provedla v něm zhodnocení odborné literatury věnované samojské kultuře, jež vyšla tiskem od doby prvního vydání díla. Anticipovala zde pozdější výhrady a kritiku. Konkrétně se vyjádřila k rivalitě mezi samojskými vesnicemi a rodinami, jak je popsali jiní antropologové - Holmes, Copp a Freeman. Komentovala i Freemanovu kritiku, kterou formuloval během jejich osobního setkání. ${ }^{8}$ Tehdy podle všeho vyjádřil názor, že na Samoa neexistuje liberální př́istup k předmanželskému sexu, ale puritánský kult panenství. Historické materiály svědčí, že se muži pokoušeli o únos taupou

7 Název prvního vydání a reedice se drobně liší v přepisu názvu lokality - Manua (vydání 1930) a Manu’a (vydání 1969).

8 Mead uvádí, že se osobně setkali poprvé v roce 1965 (Mead 1969: 227) 


\begin{tabular}{|c|c|c|c|c|c|}
\hline & lokalita & období & předmět výzkumu & $\begin{array}{l}\text { popularizační } \\
\text { práce }\end{array}$ & odborná monografie \\
\hline 1 & Samoa & $1925-1926$ & Vliv výchovy na průběh dospívání dívek & $1928 c$ & 1930 [1969] \\
\hline 2 & Manus & $1928-1929$ & $\begin{array}{l}\text { Formování a proměny osobnosti dětí } \\
\text { vlivem výchovných stylů }\end{array}$ & 1930 & 1934 \\
\hline 3 & $\begin{array}{l}\text { Rezervace } \\
\text { Omaha }\end{array}$ & 1930 & $\begin{array}{l}\text { Dopady kulturní změny na výchovné } \\
\text { styly chlapců a děvčat }\end{array}$ & - & 1932 \\
\hline 4 & $\begin{array}{c}\text { Mandátní } \\
\text { území Nová } \\
\text { Guinea }\end{array}$ & $1931-1933$ & $\begin{array}{l}\text { Studium vztahu mezi genderem } \\
\text { a temperamentem }\end{array}$ & 1935 & $\begin{array}{l}1938,1940,1947 a \\
1947 b, 1949\end{array}$ \\
\hline 5 & Bali & $1936-1938$ & Výchovné styly a péče o novorozence & - & $\begin{array}{l}1942 \text { (s Batesonem), } \\
1953 \text { (s MacGregor) }\end{array}$ \\
\hline 6 & $\begin{array}{c}\text { Mandátní } \\
\text { území Nová } \\
\text { Guinea }\end{array}$ & $1938-1939$ & Výchovné styly a péče o novorozence & - & - \\
\hline 7 & Manus & 1953 & $\begin{array}{l}\text { Kulturní změna, zvláštní pozornost } \\
\text { věnovala cargo kultu }\end{array}$ & 1956 & - \\
\hline
\end{tabular}

Tabulka 2 Přehled hlavních výzkumů realizovaných Margaret Mead.

$\mathrm{z}$ rivalitní vesnice, deflorovat je, a tím cizí vesnici zostudit. Mead si velmi dobře uvědomovala rozdíly mezi popisem Samoa, jenž zveřejnila na konci dvacátých let, a obrazem samojské kultury vylíčeným později jinými antropology. Podle Mead lze rozdíly vysvětit dvěma způsoby. Ta'u může představovat výjimku v rámci souostroví Samoa, které se jinak vyznačuje soutěživostí, rivalitou a kultem panenství. Zjevně se však kloní k druhému vysvětlení. Studovala obyčejné dospívající Samojky, nezabývala se oficiální kulturou založenou na statusu a prestiži. Jinými slovy, studovala Samoa z jiného hlediska, než činili jiní antropologové - zajímala se o dospívající dívky, jež v tichosti podle vlastní volby experimentovaly se sexem a milenci; vzdáleny soupeření o prestiž se „lehce a neuspěchaně pohybovaly smérem $k$ dospělosti“ (Mead 1969: 228).

\section{FREEMAN A SAMOA}

Mezi kolegy neměl Freeman pověst vnikajícího znalce Samoi, na ní totiž soustředil zájem až v pozdní fázi profesní dráhy. Neexistoval ani důvod, proč by měl být uznáván za předního odborníka na kulturu Samoa, do doby vydání knihy podrobující Mead kritice totiž vydal všehovšudy jen několik dílčích textů věnovaných samojské kultuře (Freeman 1943, 1947, 1964). ${ }^{9}$ Jeho diplomní práce o Samoa vyšla tiskem až pět let po jeho smrti (Freeman 2006). Freeman se v průběhu profesní dráhy zajímal především o kultury Bornea. Kolegové jej uznávali především jako skvělého znalce kultury Iban na Borneu, kde realizoval rozsáhlý terénní výzkum, na jehož základě zpracoval disertační práci a další odborné texty.

Nepochybně však nabyl bohatých znalostí samojské kultury, jelikož tam v souhrnu strávil více než šest let. Je však potřeba vzít v úvahu, že když se Freeman dostal na Samoa, přicestoval tam jako středoškolský učitel a disponoval znalostmi antropologie na úrovni úvodního univerzitního kurzu. Návrat na Samoa v šedesátých letech byl spíše vynucen okolnostmi. Při pobytu na Borneu, kde prováděl své nejvýznamnější terénní výzkumy, způsobil incident, při němž zdemoloval exponáty v místní etnografickém muzeu, nebot je pokládal za podvrhy pornografického charakteru. Na letiště jej poté odvedla policejní eskorta a na Borneu se stal nežádoucí osobou (Barnes

9 V jednom př́padě se jedná o studii na archeologické téma, $\mathrm{v}$ dalším se jedná o práci na téma př́buzenský systém na Samoi. Poslední citovaná práce je recenze na druhé vydání knihy Social Organization on Manu'a. 
2007: 349-351). Těžko tam tedy mohl pokračovat ve svých výzkumech. Jak upozornil Shankman (2009), Samoa byla logická volba - měl tam zkušenosti, ovládal místní jazyk a orientoval se v odborné literatuře $\mathrm{k}$ tématu.

Některé zdroje naznačují (Shankman 2009), že při prvním př́ijezdu na Samoa o této polynéské kultuře mnoho nevěděl, nebyl ani důvod, proč by měl. Freeman tam nepřicestoval jako antropolog. Není vůbec jisté, zda v té době vůbec znal dílo Dospívání na Samoa, jak Freeman později tvrdil (Freeman 1983: xiii). Jiné zdroje uvádějí, že během života na Samoa disponoval exempláŕi tehdy aktuálních knih od Boase General Anthropology (Obecná antropologie, 1938) a antologii děl Meadové pod názvem From the South Sea (Z Jižních moří, 1939), jež zahrnovala také Dospívání na Samoi (Apell - Madan 1988: 4-5). V té době se podle všeho hlásil k doktríně kulturního determinismu, jak ji prosazoval Franz Boas. Ideje „boasiánského paradigmatu“ mu zprostředkoval psycholog a antropolog Ernest Beaglehole (1906-1965), jenž studoval pod vedením Edwarda Sapira. Etnografický výzkum vyústil ve výše zmíněnou kvalifikační práci Sociální struktura samojské vesnické komunity, již s úspěchem obhájil. Ke zpracování tématu využil nejen etnografická data získaná mnohaletým pobytem na samojských ostrovech, ale také informace nabyté studiem v archívech Londýnské misijní společnosti, kde vyhledával a analyzoval písemné záznamy o samojských dějinách a kultuře. Výsledky vlastního terénního výzkumu publikoval spíše ojediněle, zpracoval jen několik studií, rozsáhlejším textem je pouze jeho diplomní práce, která ovšem vyšla až posmrtně (Freeman 2006).

Není na tom nic překvapivého, jelikož těžiště jeho antropologické práce se nacházelo na Borneu. Až do zveřejnění Margaret Mead a Samoa znala Freemana širší akademická obec především jako odborníka na Ibany, u nichž uskutečnil výzkum od ledna 1949 do února 1951 a následně se tam až do osudového okamžiku vracel. S využitím získaných etnografických dat zpracoval nejen disertační práci pod názvem Family and Kin Among the Iban of Sarawak (Rodina a príbuzní u Ibanů ze Sarawaku, 1953). Připravil také zprávu pro administrativu Sarawaku, jež se objevila pod titulem Report on the Iban of Sarawak (Zpráva o Ibanech ze Sarawaku, 1955) a vyšla knižně jako Iban Agriculture (Ibanské zemědělské hospodářství, 1955), jež je odborníky dodnes vysoce hodnocena.

\section{FREEMAN A MEAD}

Lze jen těžko vědět, co motivovalo Freemana ke kritice díla Mead, za níž se hnal s „buldoči vytrvalostí" (Stocking 2010: 161). Z publikovaných textů je evidentní, že Freeman nepřistupoval ke kritice s chladným rozumem, nese se v osobním duchu. Jeho veřejná vystoupení i texty obsahují mnoho zbytečných invektiv. Paul Shankman se podivuje nad schopností Freemana vměstnat urážky na jeho adresu do pouhých třech řádků. Freeman jej označil za „velkého mistra mlženi“, jenž je „intelektuálně nepoctivý, skutečný fanatik, u něhož lze doufat, že si své „pomýlené názory vezme do hrobu“ (Shankman 2009:
14). Své hlavní oponenty Paula Shankmana, Lowella Holmese, Jamese Côtéa a Martina Oranse označil za čtyři jezdce Apokalypsy, které porazí, Shankmana pak navíc považoval za jednoho ze svých největších protivníků a velkého meadofila (Shankman 2009: 13).

Freeman uvádí, že první pochybnosti o závěrech učiněných Mead o samojské kultuře pocítil již na začátku čtyřicátých let, kdy tam pobýval. Ač se v této otázce budeme pohybovat pouze na úrovni spekulací, lze o Freemanově tvrzení pochybovat. Především jej nezajímala stejná výzkumná otázka jako Mead, ale byl $\mathrm{v}$ té době stejně jako ona zastáncem striktního kulturního determinismu. Nepochybně však pojal podezření o relevantnosti výsledků prezentovaných Mead v šedesátých let, kdy s odstupem času opět prostudoval Dospívání na Samoi. Tehdy si prý předsevzal zaměřit výzkum na prověření relevantnosti výsledků dosažených a prezentovaných Mead.

Nebudeme-li počítat jejich osobní setkání v roce 1964, poprvé se Freeman $\mathrm{k}$ veřejné kritice Mead odhodlal až $\mathrm{v}$ roce 1968, kdy vystoupil na jedné konferenci s príspěvkem On the believing of as many as six impossible things before breakfest ( $\mathrm{O}$ věření až šesti neskutečným věcem ještě před snídaní), jehož název jasně odkazoval ke Carrolově prríběhu o Alence $v$ řísi divư. V př́spěvku měl poukázat na chyby, jichž se Mead dopustila ve své prezentaci samojské kultury (Apell - Madan 1988: 18). Další veřejnou kritiku předložil v recenzi na novou edici Sociálního uspořádání Manu'a. Opřel se do obou vydání uvedené práce, která v edici z roku 1969 vůbec neprošla žádnou jazykovou redakcí. Freeman v ní odhalil množství chyb $\mathrm{v}$ transliteraci samojských výrazů, jež vydavatel mechanicky přejal z původního vydání. Freeman tudíž zcela zjevně poukazuje na slabou autorčinu znalost samojštiny. Meadová přitom podle Freemana mohla sáhnout po standardních příručkách jazyka, jež mohli zájemci o samojštinu použít již v polovině dvacátých let. Freeman neopomněl k recenzi připojit rozsáhlá errata. Přidal navíc poznámku, že pracuje na publikaci, jež se bude věnovat zhodnocení textů, jež Mead napsala o samojské kultuře (Freeman 1972: 78).

Freemanův hlavní atak na závěry předložené Margaret Mead se odehrál ve dvou fázích, první proběhla v osmdesátých letech, druhá v devadesátých. Vyznačují je díla Margaret Mead a Samoa a Osudový podvod Margaret Mead. V prvním období se soustředil na důsledný rozbor díla Dospívání na $S a$ moi a dalších autorčiných prací o Samoi ve světle vlastních poznatků získaných při terénních výzkumech na začátku čtyřicátých let a v polovině těch šedesátých. $\mathrm{Z}$ díla lze odvodit sedm hlavních „bodů obžaloby“:

1. Případy, jež svědčily v neprospěch její prezentace samojské kultury jako bezkonfliktní, zmínila bud' pouze v př́ilohách, nebo je marginalizovala jako extrémy.

2. Nezohlednila skutečnost, že tradiční samojská kultura si vysoce cenila panenství. Nejvýznamnějším dokladem kultu panenství v samojské kultuře je instituce taupou princezna vesnice, jež byla př̀i sňatku veřejně deflorována.

3. Samojci nemají a nikdy neměli liberální postoj k před- 
manželskému sexu. Není to ostatně ani charakteristika žádné kultury západní Polynésie. ${ }^{10}$ Uvolněný přístup $\mathrm{k}$ předmanželskému sexu totiž zaznamenali a popsali cestovatelé ve východní Polynésii, nikoli v té západní, kde leží Samoa.

4. Samojská kultura nebyla bezkonfliktní, jak tvrdila Mead. Mezi Samojci se běžně vyskytovaly interpersonální konflikty, často vedli války, o nichž existují spolehlivé doklady. Svědčí o tom i existence boha války Le Fanoga v samojské mytologii.

5. Samojci museli být poslušní vůči autoritám, mladší vůči starším, ženy vưči mužům, obyčejní lidé vůči s tituly. Ve společenském styku se dodržovala závazná oficiální etiketa

6. Odmítnutí poslušnosti vůči výše společensky postaveným lidem se tvrdě trestalo. $Z$ tohoto hlediska se jako mladá žena nacházela $\mathrm{v}$ nevýhodné situaci, nemohla se aktivně účastnit ani oficiálních obřadů a shromáždění (fono).

7. Výchova potomků neprobíhala bezkonfliktně a péče o ně nebyla zcela rozptýlena mezi členy rozšířené rodiny, jak tvrdí Mead. Vytvářela se zde pevná vazba mezi rodiči a dětmi. Starší potomci starající se o mladší vůči nim uplatňovali svou autoritu a trestali je.

Zásadní obrat v kritice Mead nastal při prrípravě filmu Margaret Mead and Samoa (Margaret Mead a Samoa, 1988), jenž částečně vznikal i na Samoa. Dobře zpracovaný film Franka Heimase se dosud použivá na úvodních kurzech antropologie. Během tvorby snímku vyšlo najevo, že dosud žije jedna $\mathrm{z}$ informátorek, s nimiž Mead v polovině dvacátých let spolupracovala. Galea i Poumele byl synem Fofoay, tehdy již zesnulé informátorky, s níž rovněž Mead během výzkumu pracovala. Právě ten zprostředkoval Freemanovi kontakt s Fa'apua’a, tehdy již jedinou žijící pamětnicí Mead na Samoa. Rozhovor na kameru s ní vedl právě Galea'i Poumele, vysoce společensky postavený Samojec. V rozhovoru Fa'apua’a uvedla, že spolu s dalšími děvčaty tehdy Mead navyprávěly jen samé lži, když se jich vyptávala na to, co dělají v noci. Tvrdily jí, že chodí ven s mladými muži. Fáapua’a uvedla, že Mead zkrátka vzala jejich vtipkování vážně. Rozhovor překvapil samotného Freeman, jenž přepis rozhovoru s dalšími podrobnostmi následující rok zveřejnil (Freeman 1989). Freeman na tomto odhalení postavil zcela novou rétoriku i směr útoku, jenž vyústil v jeho druhou knihu a mnoho studií věnovaných Samoi a Mead.

10 Vnitřní kulturní členění Polynésie na konci třicátých let navrhl Edwin Grant Burrows (1891-1958), jenž na základě studia rozsáhlého množství pramenů rozlišil centrálně-okrajovou (orig. central-marginal) a západní Polynésii. V současné literatuře se namísto označení centrálně-okrajová užívá pojem východní Polynésie. Východní a západní Polynésii Burrows nepokládal za subareály, nýbrž za dvě hlavní polynéská kulturní centra. $K$ rozlišení dospěl na základě studia materiální kultury, sociálního uspořádání, mytologie a náboženství na dvaceti ostrovech Polynésie (Burrows 1938, 1940).
V díle Osudový podvod Margaret Mead se zaměřil na rozbor okolností terénního výzkumu provedeného Mead a vlivem Boasova pojetí kultury a antropologie na Mead. V díle se snaží doložit, že Mead uskutečnila výzkum jen v čase několika týdnů a hlavní závěry založila jen na sděleních získaných spoluprací se dvěma informátorkami, které si $\mathrm{z}$ ní navíc udělaly legraci. Z díla lze vyčíst dalších sedm „bodů obžaloby“ (Freeman 1999): ${ }^{11}$

1. Odcestovala indoktrinovaná Boasem, a proto na Samoi vykonstruovala data, pro něž jí tam Boas vyslal.

2. Nežila přímo se Samojci, ale v domě evropských přistěhovalců, kteří ji poskytli zázemí.

3. Dělila svůj čas mezi dva výzkumy, etnologický pro Bernice P. Bishop Museum a druhý pro Národní radu pro výzkum, jenž celý její pobyt a výzkum hradil.

4. Nestrávila na Samoa devět měsíců, nýbrž osm a deset dní, $\mathrm{z}$ toho celkem tři měsíce prožila na ostrově Tutuila z důvodů vyhledání místa výzkumu a osvojování jazyka.

5. Chovala se neeticky, když se nechala prohlásit za taupou, jež musela být pannou, již zjevně Mead již nebyla.

6. Nikdy neprovedla systematické zkoumání sexuálního chování adolescentních Samojek, závěry založila na rozhovorech se dvěma informátorkami.

7. Slepě uvěřila informátorkám a jejich vtipkování o promiskuitním chování samojských dívek vzala vážně.

\section{ANTROPOLOGIE A „FREEMAN VERSUS MEAD“}

Freeman zdaleka nebyl prvním a jediným kritikem Mead a jejího díla Dospívání na Samoi. Například Bronislaw Malinowski sice zprvu dílo adoroval, jak dokládá výňatek z jeho posudku, jenž se objevil na zadní straně obálky, ale později knihu kritizoval. Malinowski nejdříve označil knihu za „prvotřídní dílo deskriptivní antropologie“ a styl autorky považoval za „okouzlující a exaktní zároveñ“ (Mead 1928c: přebal), ale později zaujal ke knize kritický postoj, zejména $\mathrm{z}$ důvodu krátkého trvání výzkumu (Mead 1972). Na stránkách odborných časopisů se objevilo několik nepříznivých recenzí. Benedict a Mead se domnívaly, že se o ně postaral Sapir, jenž o těchto dvou antropoložkách šíril pomluvy, zjevně obzvlášt $\mathrm{k}$ Mead nechoval sympatie. Mimo jiné to dokládá dopis adresovaný Benedict, v němž Mead označil za „odpornou děvku“, „páchnoucí symbol všeho, co v americké kultuře nenávidi“" (cit. Banner 2004: 24).12 K raným kritikům díla patří Robert Lowie (1883-1957), jenž zpochybnil její závěry, považoval je za nepřiměřené a poukázal na rozpory obsažené $\mathrm{v}$ knize (Lowie 1929). Kritiky se Mead dostávalo po celou dobu její profesní dráhy. Kupř́íkladu můžeme citovat Marvina Harrise (1927-

11 V obou knihách se v určitých ohledech vyjmenované kritiky prolínají či opakují, zde je pro přehlednost vybírám a člením.

12 Sapir se i v univerzitních přednáškách stavěl velmi kriticky ke konfiguracionismu a premise izomorfie osobnosti a kultury, jak je rozvíjely Mead a Benedict (srov. Sapir 1994: 181-182, 191-192). 
2001), jenž jako student navštěvoval její přednášky a dobře znal její dílo. Z pozic kulturního materialismu podrobil kritice metodologii jejího výzkumu, kterou považoval za vágní a výsledky výzkumu za neverifikovatelné (Harris 2001: 407410). Harris tvrdil, že Mead prezentovala „všeobjímající etnografické všeobecnosti“, nad nimiž zůstávali mnozí kolegové stát s „údivem vykulenýma očima“ (Harris 2001: 410).

Teprve Freeman zpracoval zevrubnou kritiku díla Margaret Mead o Samoi. Mezi americkými antropology se záležitost vnímala velmi citlivě, nebot' Freemanovo dílo chápali jako útok na samotné základy kulturní antropologie položené Franzem Boasem a jeho žáky. Reakce amerických antropologů (Ember, Shore aj) na Freemanovu knihu se podle mě musí posuzovat i v souvislosti se sociobiologií, o níž se v antropologii tehdy vedla široká diskuze (srov. Segerstrale 2001). Freeman (1970, 1983: kapitola 20) i Wilson (1975, 1978), ač z jiných hledisek a s jinými cíli, odmítli předpoklad kultury jako výhradní formativní síly působící na vzorce lidského chování a prožívání. Jinými slovy, zpochybnili jednu ze základních koncepcí americké kulturní antropologie - doktrínu kulturního determinismu. Krátce po vydání Margaret Mead a Samoa zasedl speciální panel Americké antropologické asociace, jenž se věnoval Freemanově knize. Signifikantně američtí kolegové Freemana na jednání nepozvali. Panelu předsedal George Stocking, jenž tehdy nepřiznal, že byl jedním $\mathrm{z}$ recenzentů, jenž vydavateli doporučil knihu k vytištění, ač prý tehdy vyjádřil pochybnosti nad způsoby, jimiž Freeman zachází s historickými prameny (Stocking 2010: 161). Stocking se sám nezhostil rozboru kontroverze, i když na to alespoň zpočátku pomýšlel. Později připustil, že vědět jakou kontroverzi kniha vyvolá, věnoval by větší péči přezkoumání historické kontextualizace Freemanem citovaných zdrojů. Podle Stockinga to nepatřilo zrovna k Freemanovým silným stránkám (Stocking 1992: 276). Jednání panelu vedlo k závěru, že kniha Margaret Mead a Samoa je nevědecká a zavádějící a její vydání označili za nezodpovědné (Shankman 2009: 28). Kriticky se k celé kauze postavili ve speciální sekci American Anthropologist Annetta Weiner, Bradd Shore, Lowell Holmes, Martin Silverman a Theodore Schwartz (Brady 1983). Spor pokračoval na stránkách American Anthropologist i v dalším období. Kupříkladu Ember odmítl Freemanovu kritiku s odůvodněním, že nepředložil žádný důkaz a klade mu smysluplnou otázku, jak může Freeman cokoli říci o způsobech života na ostrově Ta’u ve dvacátých letech, když sám Freeman působil na Západní Samoi a ještě o patnáct let později než Mead na Americké Samoi (Ember 1985). Freeman kontroval, že těžil nejen $\mathrm{z}$ vlastních terénních poznatků, ale rovněž odvodil argumenty $z$ textů samotné Mead, v nichž našel četné rozpory, a čerpal rovněž z vládních záznamů, soudních spisů a lidí, kteří působili na Samoa ve dvacátých letech (Freeman 1985). Pozorný čtenář Freemana si nicméně povšimne, že když píše o konfliktech a násilí na Samoa, dokládá to cestovatelskou literaturou z 19. století či poznatky ze šedesátých let 20. století. Tím samozřejmě nelze bezezbytku odmítnout Freemanovu kritiku jako celek, je nicméně zjevné, že v kontroverzi je mnoho nejasností a Freemanovy argumenty nejsou vždy bezproblémové. Řada zjištění stojí proti Mead, mnohé zase naopak proti Freemanovi. Některé z nich vybírám a blíže popisuji v následujících odstavcích, abych demonstroval komplikovanost sporu.

Mead v Dospívání na Samoa prezentuje polynéské ostrovy jako ukázku světa „ušlechtilých divochü“ nezkažených civilizací. ${ }^{13}$ Podle Shankmana (2009) tím reagovala na idealizovanou představu tropického ráje na tichomořských ostrovech, jíž si na základě knih a filmů Američané vytvořili. Ve dvacátých letech měli možnost shlédnout romantické snímky Moana (1926) či White Shadows in the South Seas (Bílé stíny v Jižních mořích, 1928), jež vznikly v Polynésii, první z nich přímo na Samoi. O popularizaci Polynésie jako rajských ostrovů se postaral rovněž literát Robert Louis Stevenson (1850-1954), jenž na sklonku života několik let cestoval Tichomořím, kde také nakonec zesnul. Shodou okolností na souostroví Samoa. Polynésie ovlivnila nejen jeho pozdní literární dílo, ale své zkušenosti sepsal v široce čteném díle The South Seas (Jižní moře, 1896) ${ }^{14}$. Dospívání na Samoa nepochybně nese výrazný otisk představ o Tichomoří, jež si Američané díky filmům a knihám utvořili. Je však také dost dobře možné, že tvrzení Mead o liberálním přístupu samojských děvčat $\mathrm{k}$ předmanželskému sexu, jsou projekcí vlastních životních zkušeností a postojů autorky. Mead zastávala na svou dobu velmi neobvyklé názory na partnerské vztahy, sex a manželství. Nehodlala se nechat nikým a ničím svazovat. Když například cestovala do Polynésie, poslala manželovi dopis, v němž mu bez obalu napsala, že jej neopustí, ledaže by našla někoho, koho bude milovat více (Freeman 1999: 66). Povšimněme si také např́íklad, jak za studijních let Mead vnímala svi̊j přesun z Indiany do New Yorku. Pobyt na DePauwově univerzitě popsala jako život v exilu, znalostmi, postoji a aktivitami nezapadala mezi spolužáky, dokonce i styl oblékání stál proti ní (Mead 1972: 99-100). Oproti tomu New York jí umožnil plně se oddat nezávislému a „single životu“. Metropole umožňovala to, co v jiných částech země nepřipadalo v úvahu, tam dívka žila $s$ rodiči až do svatby, mladíci se dvořili dívkám pod dozorem rodičů, dívka zůstávala obvykle panna až do svatby. New York nabídl mladé studentce zcela nové př́ležitosti a zkušenosti (Shankman 2009: 75). Na závěry výzkumu na Samoi můžeme tudíž hledět také optikou osobních zkušeností autorky nasbíraných v New Yorku a projikovaných na Samoa. Je v každém prŕípadě zcela zjevné, že její prezentace Samoy se nedrží dat, jež sama autorka získala během terénního výzkumu. Jak totiž zjistil Orans, Mead uvedla v Dospívání na Samoi více negativních informací o Samojcích než pozitivních, přesto je samojská kultura prezentována jako klidná a bezkonfliktní (Orans 1996: 153).

Odborníci se shodují, že Freeman mohl jen stěží studovat předmanželský život samojských děvčat. Trefně vyjádřila podstatu argumentu Scheper-Hughes, když napsala, že pokud

13 Není bez zajímavosti, že francouzští filozofové skutečně považovali některé polynéské ostrovy za domov „ušlechtilých divochü“ (Kirch 2002: 4).

14 Český překlad obsahuje jen výběr z díla (viz Stevenson 1977). 
by Freeman kladl samojským děvčatům stejné otázky jako Mead, prchal by z ostrovů s nálepkou „staré prase“ (Scheper-Hughes 1987: 449). Nelze zpochybnit, že spíše Mead než Freeman mohla studovat sexualitu samojských adolescentních děvčat. Na druhou stranu Mead publikací Dospívání na Samoi porušila hned několik samojských norem. Ctnost žen a dodržování společenské etikety patří $\mathrm{k}$ nejvýznamnějším samojským hodnotám. Diskuze o intimním životě se sice připouští, ale toliko $\mathrm{v}$ privátních rozhovorech sdílených jen $\mathrm{v}$ úzkém okruhu zúčastněných. Na veřejnosti se připouští jen na rovině žertů, ženy s muži na téma sexuality na veřejnosti nehovoří vưbec. Mead publikací Dospívání na Samoi tudíž porušila etiketu, když informace získané $\mathrm{v}$ soukromých rozhovorech učinila veřejnými, dostala je do zcela nevhodného kontextu. ${ }^{15}$ Pokud si skutečně dvě Samojky z Mead udělaly legraci, jak tvrdí Freeman, bylo by to v souladu s etiketou rozhovoru na téma sexuality na veřejnosti.

Freeman od konce osmdesátých let změnil rétoriku, když vyšlo najevo svědectví Fa'apua’ay, která měla být spolu s dívkou jménem Fofoa zodpovědná za „nevinnou lež“ o premaritální promiskuitě samojských dívek. Od té doby soustředil své síly na doložení tvrzení, že Mead málo rozuměla samojské kultuře a jazyku, a tudíž se nechala snadno ošálit svými informátorkami, jež jí napovídaly, že si užívají podle chutě předmanželského sexu. Objevily se však názory a doklady, že Freemanova prezentace a výklad obsahu svědectví Fa'apua‘ay je tendenční a neúplná. Vůdčím kritikem se stal Paul Shankman, jenž se kontroverzi Freeman versus Mead dlouhodobě věnuje a zjevně se nekloní na Freemanovu stranu. Shankman uvádí, že Fa'apuáa nevěděla, co Mead na základě svých zjištění o Samoi a místních dospívajících dívkách napsala. Jako praktikující křestanka se rozhodla učinit doznání na kameru, nebot' se domnívala, že svým žertem uvedly Mead v omyl, jež pak psala o předmanželské promiskuitě samojských děvčat. Shankman zastává názor, že se Fáapuaáa dostala do prekérní situace, musela porušit normu zakazující konverzaci žen s muži o sexu, navíc se musela držet etikety regulující rozhovor mezi ženou a vysoce společensky postaveným mužem. Ve filmu zachycená odpověd’ vysoce společensky postavenému muži tudíž zřejmě odráží potřebu zachovat pověst nejen samojských žen, ale rovněž ctnost Fa'apua'ay a Fofoay, které, at již to bylo s jejich premaritální promiskuitu jakkoli, nyní neměly díky Mead na veřejnosti pověst žen dobrých mravů (Shankman 2009: 41). Existují pochybnosti, že Fa'apuáa vůbec byla klíčovou informátorkou. Maritn Orans nedokázal v Dospívání na Samoi a v terénních poznámkách vedených Mead identifikovat žádný odkaz na premaritální promiskuitu, který by směřoval $\mathrm{k}$ této Samojce $\mathrm{V}$ Dospívání na Samoi ji Mead dala jméno Pana a věnovala jí všehovšudy pár obecných vět, ${ }^{16}$ zjevně se tedy nejednalo o klíčovou in-

15 Mead uvedla, že ji ani nenapadlo, že by si knihu mohli Samojci kdy prečíst.

16 Píše o ní jako o taupo ve věku 26 let, stále ještě svobodná dívka se měla vdávat a bylo nutné najít její následnici (Mead 1928c: 52). Více informací Mead neuvedla. formátorku (Orans 1996). Freeman tvrdil, že v pokročilém věku bližícím se devadesátce měla Fa'apua'a výbornou pamět (Freeman 1999: 2-3). Záznam tří interview (v letech 1987, 1988 a 1993), jež s ní vedl Freeman a jeho pomocník Unasa, však ukazuje, že si ve výpovědích často protiřečila, zapomínala a nevzpomínala si jasně (Shankman 2013). Navíc hodnotu rozhovorů podle mého názoru snižuje skutečnost, že Freeman, Unasa a Galea i Poumele byli nejen muži, ale rovněž vysoce společensky postavení s tradičními tituly.

Americká kulturní antropologie patřila v polovině dvacátých let $\mathrm{k}$ plně etablovaným univerzitním oborům. Metodologie stacionárního terénního výzkumu však v té době ještě nebyla zcela vyjasněna a prosazena. Teprve tři roky před odjezdem Mead na Samoa vyšla stěžejní práce Malinowského (1922), v němž popsal základní principy realizace stacionárního terénního výzkumu. Mead knihu v té době neznala, o metodách a technikách výzkumu se jí dostalo jen stručného školení od Boase krátce před odjezdem (Mead 1972). Nelze jí však upřít, že ve své době uskutečnila terénní výzkum způsobem, jenž převyšoval dobové standardy v americké kulturní antropologii. Její američtí kolegové zpravidla realizovali terénní výzkum během letních měsíců v indiánských rezervací, jejich znalost nativního jazyka obvykle sestávala z osvojení základních slovíček a frází. Oproti nim se Mead věnovala výzkumu více než osm měsíců a podstoupila intenzivní jazykovou př́pravu. Obdobně jako Malinowski kladla důraz na znalost jazyka kultury, kterou studovala. Freemanovo (1983: 286) obvinění Mead z neznalosti samojštiny není zjevně na místě. Mead podle všeho ovládala samojštinu do té míry, že dokázala nejen porozumět rozhovorům, ale prŕležitostně dokonce vypomáhala jako tlumočnice mezi samojštinou a angličtinou. Chyby v transliteraci, na něž poukázal Freeman (1972), lze vysvětlit tím, že jazyk nestudovala formálně, ale užívala jej jako nástroj komunikace (Mead 1969: 213; srov. Orans 1996: 20-21, Shankman 2005). Z hlediska dnešního stavu metod a technik terénního výzkumu lze jistě Mead leccos vytknout, v té době se však nepochybně jednalo o nadstandardně provedený výzkum - dlouhodobě pobývala v dané kultuře, vstupovala do interakce s domorodci, vedla s nimi etnografická interview s využitím, byt’ omezené, znalosti místního jazyka.

\section{ZÁVĚR}

Spor Freeman versus Mead zaměstnává antropology již více než třicet let. Nadále vycházejí najevo nové skutečnosti, artikulují se nová hlediska a stanoviska, dosud kontroverze rozděluje antropology. $\mathrm{S}$ přihlédnutím $\mathrm{k}$ výše uvedeným faktům lze přirozeně tvrdit, že obraz Samoy jako sexuálního ráje, jak jej Mead popsala v Dospívání na Samoi, není nic více než projekce vlastních tužeb a osobních zkušeností autorky. Je zcela nepochybné, že lze odvrhnout nemálo tvrzení Mead o Samoa. Freemanovo úsilí o vyvrácení samojských omylů, o něž se díky Mead opírala kulturní antropologie více než půl století, je $\mathrm{z}$ tohoto hlediska správná. $\mathrm{Z}$ jeho zaujetí Mead a razance a nasazení, s níž usiloval o její diskreditaci, je evidentní, že 
jeho atak mohl mít osobní rozměr. Snad má pravdu Mary Catherine Bateson (narozena 1939). Vyslovila totiž názor, že Freeman musel cítit frustraci $\mathrm{z}$ všudypř́ítomnosti Mead. Při práci o samojské kultuře se neustále setkával s komentáři k Dospívání na Samoi a citacemi Mead, a tak stál setrvale v jejím stínu (Bateson 1984: 224). Freeman uvedl (1983: xv), že jej sami Samojci požádali, aby provedl revizi závěrů obsažených v Dospívání na Samoi, nebot' se s nimi neztotožňovali. Ovšem ani jeho popis Samojců jako sexuálně strádajících násilníků u nich nenašel podporu. Nabízí se přirozeně logická otázka, zda Samojce uspokojilo, že veřejný obraz jejich ostrovů jako tropického ráje obydleného lidmi otevřenými volné lásce nahradil obraz kultury naplněné konflikty, rivalitou a sexuálním strádáním. Mnozí přední představitelé Samoy opravdu striktně odmítli závěry obou antropologů. Lelei Lelaulu, jeden z představitelů Západní Samoi, ironicky a současně trefně poznamenal (cit. Shankman 2009: 145), že pokud antropologové chtějí studovat sex a násilí, měli by se odebrat na jiný ostrov - jmenuje se Manhattan.

\section{LITERATURA}

Appell, George - Madan, Triloki (1988): Derek Freeman: Notes Toward an Intellectual Biography. In: Appell, George - Madan, Triloki, eds., Choice and Morality. Albany: State University of New York Press, 3-26.

Banner, Lois (2004): Intertwined Lives: Margaret Mead, Ruth Benedict, and Their Circle. New York: Vintage.

Barnes, J. A. (2007): Humping My Drum. S.1.: Lulu.

Barrowclough, Nikki (1996): Sex, Lies, and Anthropology. Sydney Morning Herald Magazine, 9. března, 31-39.

Bateson, Gregory - Mead, Margaret (1942): Balinese Character. New York: New York Academy of Sciences

Bateson, Mary Catherin (1984): With a Doughter's Eye. New York: William Morrow.

Boas, Franz (1962): Anthropology and Modern Life. New York: Dover Publication.

Braddy, Ivan, ed. (1983): Speaking in the Name of the Real: Freeman and Mead on Samoa. American Anthropologist, 85(4), 908-909.

Budil, Ivo T. (2003): Mýtus, jazyk a kulturní antropologie. Praha: Triton.

Burrows, Edwin (1938): Western Polynesia, a study in cultural differentiation. Ethnological studies, 7, 1-192.

Burrows, Edwin (1940): Culture-Areas in Polynesia. Journal of the Polynesian Society, 49(3), 349-363.

Caton, Hiram (1990): The Samoa Reader. Lanham: University Press of America.

Ember, Melvin (1958): Commercialization and Political Behavior in American Samoa. New Haven: Yale University

Ember, Melvin (1985): Evidence and Science in Ethnography: Reflections on the Freeman-Mead Controversy. American Anthropologist, 87(4), 906-910.

Freeman, Derek (1970): Human Nature and Culture. In Man and the New Biology. Slatyer, Ralph, ed., Canberra: Australian National University Press, $50-75$

Freeman, Derek (1972): Social Organization of Manu'a by Margaret Mead: Some Errata. Journal of the Polynesian Society, 81, 70-78.

Freeman, Derek (1980): Sociobiology: „antidiscipline of Anthropology. In: Montagu, Ashley, ed., Sociobiology Examined. New York: Oxford University Press, 198-219.

Freeman, Derek (1983): Margaret Mead and Samoa. Harvard: Harvard University Press.

Freeman, Derek (1985): A Reply to Ember's Reflections on the Freeman-Mead Controversy. American Anthropologist, 87(4), 910-917.
Freeman, Derek (1989): Fa’apua’a Fa’amû and Margaret Mead. American Anthropologist, 91(4), 1017-1022.

Freeman, Derek (1991): There's Tricks i' th' World: An Historical Analysis of the Samoan Researches of Margaret Mead. Visual Anthropology Review, $7(1), 103-128$.

Freeman, Derek (1992): Paradigms in Collision: The Far-Reaching Controversy over the Samoan Researches of Margaret Mead and Its Significance for the Human Sciences. Academic Questions, 5(3), 23-33.

Freeman, Derek (1997): Paradigms in Collision: Margaret Mead's Mistake and What It Has Done to Anthropology." Skeptic, 5(3), 66-73.

Freeman, Derek (1999): The Fateful Hoaxing of Margaret Mead. Boulder: Westview Press.

Freeman, Derek (2000): Was Margaret Mead Misled or Did She Mislead on Samoa? Current Anthropology, 41(4), 609-14.

Freeman, Derek (2006): The Social Structure of a Samoan Village Community. Canberra: Target Oceania.

Hall, Granville (1904): Adolescence. 2 sv. Englewood Cliffs: Prentice-Hall.

Harris, Marvin (2001): The Rise of Anthropology Theory. Walnut Creek: Altamira Press.

Holmes, Lowell (1974): Samoan Village. New York: Holt, Rinehart and Winston.

Holmes, Lowell (1988): Quest for the Real Samoa. Hadley: Bergin \& Garvey. Keesing, Felix (1934): Modern Samoa. London: G. Allen \& Unwin.

Kirch, Patrick (2002): On the Road of the Winds. Berkeley: University of California Press.

Kramařík, Josef - Nahodil, Otokar, eds. (1953): Anglo-americká ethnografie ve službách imperialismu. Praha: Československo-sovětský institut.

Lowie, Robert (1929): Coming of Age in Samoa. A Psychological Study of Primitive Youth for Western Civilisation. Margaret Mead. Foreword by Franz Boas. American Anthropologist, 31(3), 532-534.

Lutkehaus, Nancy (2008): Margaret Mead. Princeton: Princeton University Press.

Mageo, Jeanette (1998): Theorizing Self in Samoa. Ann Arbor: University of Michigan Press.

Malinowski, Bronislaw (1922): Argonauts of the Western Pacific. London: Kegan Paul, Trench, Trubner.

Mead, Margaret - MacGregor, Frances (1953): Growth and Culture. New York: Putnam.

Mead, Margaret (1928a): The Role of the Individual in Samoan Culture. The Journal of the Royal Anthropological Institute of Great Britain and Ireland, 58(2), 481-495.

Mead, Margaret (1928b): An Inquiry into the Question of Cultural Stability in Polynesia. New York: Columbia University Press.

Mead, Margaret (1928c): Coming of Age in Samoa. New York: William Morrow.

Mead, Margaret (1928d): The Maoris and Their Art. New York: American Museum of Natural History.

Mead, Margaret (1928e): A Lapse of Animism Among a Primitive People. Psyche, 90, 72-77.

Mead, Margaret (1929): The Samoan Kilt. The Journal of Polynesian Society, 38(151), 239.

Mead, Margaret (1930): Growing Up in New Guinea. New York: William Morrow.

Mead, Margaret (1932): The Changing Culture of an Indian Tribe. New York: Columbia University Press.

Mead, Margaret (1934): Kinship in the Admirality Islands. Anthropological Papers of the American Museum of Natural History, 34(2), 181-358.

Mead, Margaret (1935): Sex and Temperament in Three Primitive Societies. New York: William Morrow.

Mead, Margaret (1937): The Samoans. In: Mead, Margaret, ed., Cooperation and Competition Among Primitive Peoples. New York: McGrave-Hill, 282-312.

Mead, Margaret (1938): The Mountain Arapesh: I. An Importing Culture. Anthropological Papers of the American Museum of Natural History, 36(3), 141-349.

Mead, Margaret (1940): The Mountain Arapesh: II. Supernaturalism. Anthropological Papers of the American Museum of Natural History, 37(3), 317-451.

Mead, Margaret (1947a): The Mountain Arapesh: III. Socio-Economic Life. 
Anthropological Papers of the American Museum of Natural History, 40(3), 171-232.

Mead, Margaret (1947b): The Mountain Arapesh: IV. Diary of Events in Alitoa. Anthropological Papers of the American Museum of Natural History, 40(3), 233-419.

Mead, Margaret (1949): The Mountain Arapesh: V. The Record of Unabelin With Rorschach Analyses. Anthropological Papers of the American Museum of Natural History, 41(3), 287-390.

Mead, Margaret (1956): New Lives for Old. New York: William Morrow.

Mead, Margaret (1956): Some Relationships Between Social Anthropology and Psychiatry. In: Alexander, Franz - Ross, Helen, eds., Dynamic Psychiatry. Chicago: University of Chicago Press, 401-448.

Mead, Margaret (1964): Male and Female. Harmondsworth: Penguin.

Mead, Margaret (1969): Social Organization of Manu'a. Honolulu: Bernice P. Bishop Museum.

Mead, Margaret (1972): Blackberry Winter. New York: William Morrow.

Mead, Margaret (1973): Coming of Age in Samoa. New York: William Morrow.

Mead, Margaret (1977): Letters from the Field: 1925-1975. New York: Harper Colophon Books.

Mead, Margaret (2010): Pohlaví a temperament ve třech primitivních společnostech. Praha: Sociologické nakladatelství.

Moyle, Richard (1981): Fägogo: fables from Samoa in Samoan and English. Auckland: Auckland University Press.

Moyle, Richard (1988): Traditional Samoan music. Auckland: Auckland University Press.

Orans, Martin (1996): Not Even Wrong. Novat: Chandler \& Sharp.

Popper, Karl (1994): Bída historicismu. Praha: Oikoymnenh.

Rensberger, Boyce (1984): Geny a kultura - spor pokračuje. Spektrum, 45, 32-38.

Sapir, Edward (1924): Anthropology at the Toronto Meeting of the British Association for the Advancement of Science. American Anthropologist, 26(4), s. 563-565.

Sapir, Edward (1994): The Psychology of Culture. Berlin: Mouton de Gruyter.

Segerstrale, Ullica (2001): Defenders of the Truth. Oxford: Oxford University Press.

Shankman, Paul (1996): The History if Samoan Sexual Conduct and tie Mead-Freeman Controversy. American Anthropologist, 98(3), 555-567.

Shankman, Paul (2005): Margaret Mead's Other Samoa: Rereading Social Organization of Manu'a. Pacific Studies, 28(3/4), 46-59.

Shankman, Paul (2009): The Trasing of Margaret Mead. Wisconsin: The University of Wisconsin Press.

Shankman, Paul (2013): The „Fateful Hoaxing“ of Margaret Mead: Cautionaty Tale. Current Anthropology, 54(1), 51-70.

Shore, Bradd (1977): A Samoan Theory of Action. Disertační práce. Chicago: University of Chicago.

Shore, Bradd (1982): Sala'ilua. New York: Columbia University Press.

Scheper-Hughes, Nancy (1987): The Margaret Mead Controversy: Culture, Biology and Anthropological Inquiry. In Applebaum, Herbert, ed., Perspectives in Cultural Anthropology. Albany: State University of New York Press, 443-454.
Schoeffel, Penelope (1979): Daughters of Sina. Disertační práce. Canberra: Australian National University.

Soukup, Martin (2013): Antropologie a Melanésie. Praha: Karolinum.

Soukup, Václav (2004): Dějiny antropologie. Praha: Karolinum.

Stocking, George (1992): The Ethnographer's Magic and Other Essays in the History of Anthropology. Wisconsin: University of Wisconsin Press.

Stocking, George (2010): Glimpses Into My Own Black Box. Wisconsin: University of Wisconsin Press.

Voráček, Josef (1941): Primitivní rodina. Praha: Česká akademie věd a umění.

Vrhel, František (2010): Matriarcha genderových studií. In: Mead, Margaret, Pohlaví a temperament ve třech primitivních společnostech. Praha: Sociologické nakladatelství, 328-341.

Wilson, Edward (1975): Sociobiology. Harvard: Belknap Press.

Wilson, Edward (1978): On Human Nature. Harvard: Harvard University Press.

Wolf, Josef, ed. (1971a): Sociální a kulturní antropologie. Praha: Svoboda.

Wolf, Josef, ed. (1971b): Úvod do studia člověka IV. Praha: Státní pedagogické nakladatelství.

\section{AUTOR}

Soukup, Martin (26. 3. 1977, Praha), sociální a kulturní antropolog. Absolvoval Filozofickou fakultu Univerzity Karlovy v Praze, kde působil v letech 2009-2015 jako odborný asistent a později docent. Nejdřive na katedře teorie kultury a následně na Etnologickém ústavu. V současnosti působí na katedře sociologie, andragogiky a kulturní antropologie Filozofické fakulty Univerzity Palackého v Olomouci a v Náprstkově muzeu asijských, afrických a amerických kultur. Předmětem jeho odborného zájmu jsou dějiny, teorie a metodologie anglosaské antropologie. Zvláštní pozornost věnuje vizuální antropologii, antropologii těla a kulturnímu areálu Melanésie. Uskutečnil trři terénní výzkumy na Papui-Nové Guineji (2009, 2011, 2015), konkrétně pobýval u etnické skupiny Nungon v provincii Morobe. Kromě množství odborných studií je autorem či spoluautorem řady knih: Základy kulturní antropologie (2009), Biokulturologie (2010), Kultura (2011; rozšířené a přepracované vydání Biokulturologie), Nungon People of Uruwa (2012, společně s Julií Hubeňákovou), kolektivní monografie Tělo (2014), Terénní výzkum v sociální a kulturní antropologii (2014). Rozsáhlá monografie Antropologie a Melanésie (2013) byla oceněna jako nejlepší monografie Univerzity Karlovy v Praze za rok 2015. Je členem American Anthropological Association, European Society of Oceanists a České geografické společnosti.

Kontakt: Doc. PhDr. Martin Soukup, Ph.D.; e-mail: soukup@antropolog.cz; homepage: www.antropolog.cz. 